\title{
Effect of global change on bivalve rearing activity and the need for adaptive management
}

\author{
Donata Melaku Canu ${ }^{1}$, Cosimo Solidoro ${ }^{1, *}$, Gianpiero Cossarini $^{1}$, Filippo Giorgi ${ }^{2}$ \\ ${ }^{1}$ Istituto Nazionale di Oceanografia e di Geofisica Sperimentale - OGS, Borgo Grotta Gigante, Brisciki 42/c, \\ 34010 Sgonico-Zgonik (Trieste), Italy \\ ${ }^{2}$ International Centre for Theoretical Physics, Strada Costiera, Trieste, Italy
}

\begin{abstract}
A downscaling experiment linking a regional atmospheric model to local ecosystem and target species population dynamics models was conducted to evaluate the effects of IPCC climate change scenarios on a temperate coastal lagoon ecosystem, the lagoon of Venice (Italy), along with goods and services provided by this ecosystem. Our results indicate that the changes in water temperature and reduction in plankton productivity caused by the modification of seasonal precipitation patterns will affect habitat suitability for clam growth and aquaculture. Simulations show that aquaculture, which has substantial economic value, will suffer, and they highlight the need for management policies to mitigate the adverse effects of climate change. Extrapolation of these conclusions to other coastal systems might be particularly relevant for socio-economic systems in which clam farming is crucial for a self-sustaining economy.
\end{abstract}

KEY WORDS: Downscaling $\cdot$ Clam aquaculture $\cdot$ Venice $\cdot$ Global change $\cdot$ Ruditapes philippinarum Adaptive management $\cdot$ Socio-ecological system $\cdot$ Thermal adaptation

\section{INTRODUCTION}

Global Change (GC) is expected to have strong effects on the structure and function of both pelagic and coastal ecosystems. The effects may be more critical in shallow coastal areas, where a variety of different anthropogenic stressors, such as pollution, nutrient enrichment and fishing, already impact the local ecological integrity. Considering that many economic activities rely on goods and services that depend on the ecological quality of coastal areas, GC might thus have a substantial impact on quality of life, especially in developing countries where adaptation to GC might be more challenging. In particular, locally effective adaptive strategies may be required to tackle localised impacts of GC (Hulme 2005, Harley et al. 2006, Nicholls et al. 2007). Ecological and ecosystem modelling tools can be used to assess the magnitude of GC impacts and evaluate the effects of alternative policies (Harley et al. 2006).
Besides the obvious direct effects of temperature increases, GC might impact aquaculture activities and the dynamics of biogeochemical properties by inducing changes in nutrient input. For example, GC can induce changes in system trophodynamics by altering the precipitation regime and consequent riverine inputs from the drainage basin (Scavia et al. 2003, Boesch et al. 2000). Results obtained in a downscaling experiment for the lagoon of Venice, Italy (Cossarini et al. 2008, Salon et al. 2008), indicate that changes in the timing and volume of freshwater discharge and nutrient input induced by GC are critical in defining the seasonal dynamics of biogeochemical properties. Future climate projections suggest that annual mean precipitation will not change substantially over the Venice Lagoon watershed, whereas seasonal patterns of precipitation will likely change, with summer and spring becoming drier and winter and autumn becoming rainier (Salon et al. 2008). This will potentially increase nutrient concentrations in winter and decrease 
them in spring and summer (Cossarini et al. 2008). Given that environmental conditions other than nutrients are more favourable to plankton productivity during spring and summer than in fall or winter (Solidoro et al. 2005), GC will also cause an overall decrease in annual primary and secondary plankton production and an increase in the export of unutilised nutrients to the Adriatic Sea during the colder seasons (Cossarini et al. 2008).

In this study, we explored the impacts of GC on local aquaculture activities in a temperate coastal area and the importance of implementing adaptive management policies to mitigate adverse effects, using the lagoon of Venice as a case study. In particular, we explored how changes in the seasonal dynamics of temperature and biogeochemical properties (Cossarini et al. 2008) affect the rearing of the Manila clam Ruditapes philippinarum, an economically important species for local fisheries and aquaculture. To that end, a bioenergetics model describing the growth and population dynamics of clams in this study area (Solidoro et al. 2000, 2003) was integrated with the hierarchy of models used in the downscaling experiment (Cossarini et al. 2008, Solidoro et al. 2010b). This integration enabled us to analyse the impacts of state-of-the-art climate change projections for the region (Giorgi et al. 2004a,b, Gao et al. 2006) on $R$. philippinarum by explicitly linking the output from climate model simulations to physiological models of clams. This gave our study an integrated and comprehensive perspective of climatic, ecological and socio-economic aspects of a coastal marine ecosystem. Previous studies focused on the impact of GC on physical and biogeochemical properties without considering higher trophic level organisms (Vichi et al. 2003, Cossarini et al. 2008), the response of target organisms to environmental modifications without linking those modifications back to GC (Dekshenieks et al. 2000, Vincenzi et al. 2006), or economic consequences of hypothetical management scenarios that are not explicitly related to climate change (Marinov et al. 2007, Spillman et al. 2009).

Here we analysed two 30 yr time windows: presentday conditions (1961-1990) and conditions in future decades of the 21st century (2071-2100) under the A2 IPCC greenhouse gas emission scenarios (Jones et al. 2001). The effects of different management options were also compared to select the 'best' strategies for present or projected future climate conditions. In this way, we investigated whether the effects of GC will necessitate modification of management policies, an uninvestigated issue in previous modelling studies of clam aquaculture (Pastres et al. 2001, Marinov et al. 2007, Spillman et al. 2009). According to FAO (2008), the vulnerability of Ecological-Social-Economic (ESE) systems to GC is determined by non-linear interactions of 3 factors: exposure, sensitivity to change and the ability to respond to, or even take advantage of, change. Our study therefore provides a methodological example for other coastal ecosystem downscaling analyses, and gives general insights into the effects of $\mathrm{GC}$ on coastal areas and the effectiveness of different adaptation policies.

The paper is organised as follows: Section 2 provides a brief description of the study site and frames the aquaculture activity within the local socio-economic context. It also describes the models used in the downscaling experiments and how they were integrated within the model hierarchy. Section 3 discusses the projected consequences of present-day and future scenarios, and Section 4 presents a summary of our main conclusions.

\section{MATERIALS AND METHODS}

\subsection{Aquaculture of Ruditapes philippinarum in the lagoon of Venice}

The lagoon of Venice, the largest Italian lagoon, lies off the northern Adriatic Sea and covers a surface area of about $550 \mathrm{~km}^{2}$, with an average depth of about $1 \mathrm{~m}$ (Fig. 1). It is a transitional environment that has been subjected to strong anthropogenic impacts for many centuries (Solidoro et al. 2010a). Circulation in the lagoon results from tidal action, wind and morphological constraints (Melaku Canu et al. 2003). Fluxes through the 3 inlets amount to about one-third of the total lagoon volume per tidal cycle, and residence times vary from a few days (closer to the inlets) to up to $1 \mathrm{mo}$ (in the inner portion; Solidoro et al. 2004a, Cucco et al. 2009). The lagoon receives freshwater discharges from 11 major tributaries, several minor rivers and a number of channels used primarily for agriculture. The drainage basin covers about 2000 $\mathrm{km}^{2}$, mainly in intensively cultivated areas. Presently, the rivers carry a high nutrient load roughly equivalent to $4000 \mathrm{t} \mathrm{N} \mathrm{yr}^{-1}$ and $200 \mathrm{t} \mathrm{P} \mathrm{yr}^{-1}$ (Cossarini et al. 2009). The exchanges with the Adriatic Sea and inputs of freshwater and nutrients from the drainage basin sustain marked gradients in salinity and nutrient concentrations (Melaku Canu et al. 2003, Solidoro 2004b), which are reflected in the spatial succession of a variety of habitats from the mainland to the sea (Bandelj et al. 2008, 2009). In addition to a standard latitudinal partitioning into 4 sub-basins (south, central, north-central and north), a longitudinal subdivision of the lagoon along a gradient of residence time (confinement, sensu Guelorget \& Perthuisot 1992) is also often considered (Solidoro et al. 2004a, 2010a, Marchini \& Marchini 2006). 


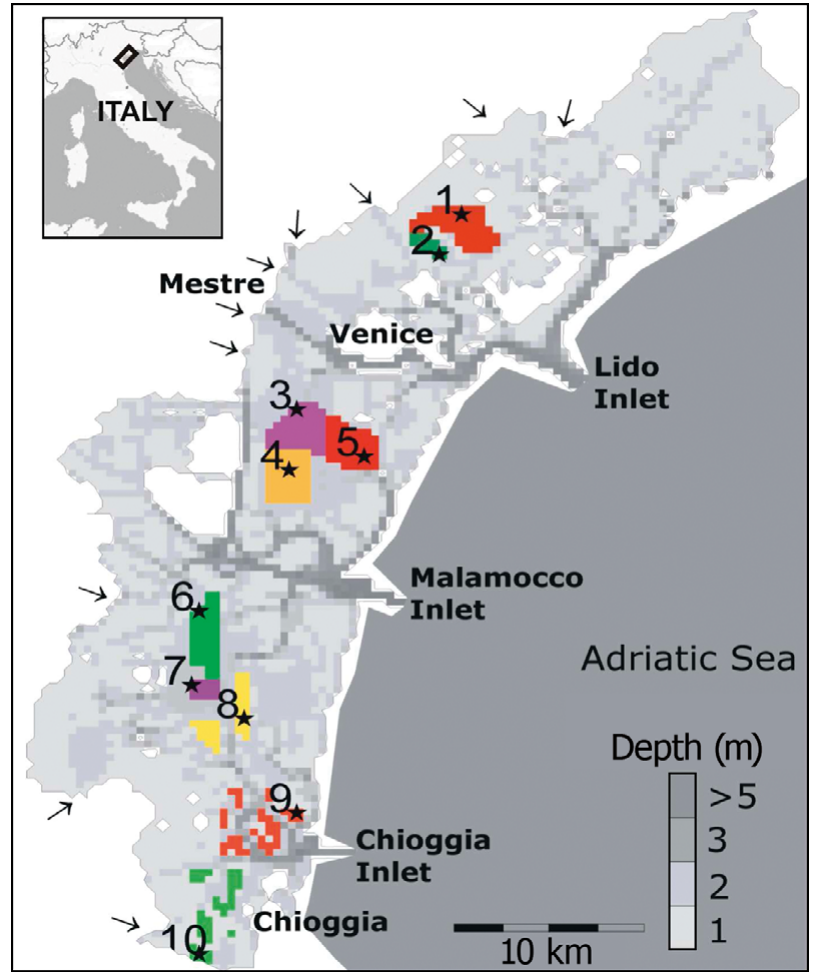

Fig. 1. Lagoon of Venice. Bathymetry (grey scale), aquaculture concessions (coloured areas) and position of lots used for Cascade A simulations (stars). Arrows indicate the main rivers emptying into the lagoon

Ruditapes philippinarum is an allochthonous species introduced into the lagoon of Venice in 1983 by a regional governmental agency, Sviluppo Pesca ed Acquacultura Veneta (COSPAV; Pellizzato 1990), to assess the lagoon's suitability for commercial production. R. philippinarum rapidly spread throughout the basin and soon became the most profitable fishing resource (Solidoro et al. 2000). Local authorities were not able to govern the subsequent exploitation, which took place very fast, without regulation and sometimes illegally (Melaku Canu et al. 2002). This created social, environmental, sanitary and socio-economic problems of increasing complexity (Pastres et al. 2001, Melaku Canu et al. 2002, Solidoro et al. 2010a). Market data corrected for unofficial landings (Fig. 2) and used as a proxy of clam production in the lagoon show a positive trend peaking in 1996-1999, with a yearly production of about $40000 \mathrm{t}$ of clams, followed by a marked decline to values as low as $17500 \mathrm{t} \mathrm{yr}^{-1}$ in 2002 (possibly indicating overexploitation) and production of about $25000 \mathrm{t} \mathrm{yr}^{-1}$ from 2003 to 2007 (Solidoro et al. 2000, Melaku Canu et al. 2002, Boatto et al. 2005, Pellizzato \& Da Ros 2005, Zentilin et al. 2008, Torricelli et al. 2009). Market price evolution shows the opposite trend (Boatto et al. 2005, Torricelli et al. 2009), with stable values from 2003 to 2007 (Fig. 2). The total gross economic value is 85 to 100 million Euros $\mathrm{yr}^{-1}$. During the period of highest productivity, some 2000 people were working in the clam industry.

Despite the recent reduction in landings, Ruditapes philippinarum remains a very important resource in the lagoon. Market data referring to other lagoon species (Torricelli et al. 2009) indicate that the total landings of lagoon species, excluding $R$. philippinarum, in 2000-2006 were around $8000 \mathrm{t} \mathrm{yr}^{-1}$. Aside from their economic value, fishing and aquaculture are socially and culturally important. For instance, they help sustain the smaller islands' social structure, provide an alternative economic activity to tourism and preserve a body of knowledge and traditions derived from centuries of close interactions between the lagoon and its inhabitants.

In the 1990s, aquaculture was identified as a possible alternative to unregulated access to the resource because it would maintain a substantial economic income while significantly reducing the lagoon area devoted to clam harvesting. It would also increase the density, productivity and quality of clams in cultivated lots and ultimately reduce environmental impacts and external costs imposed upon the society (negative externalities). Early studies (Orel et al. 2000) and modelling projections (Melaku Canu 1998, Melaku Canu et al. 2002, Pastres et al. 2001) suggested that in the lagoon of

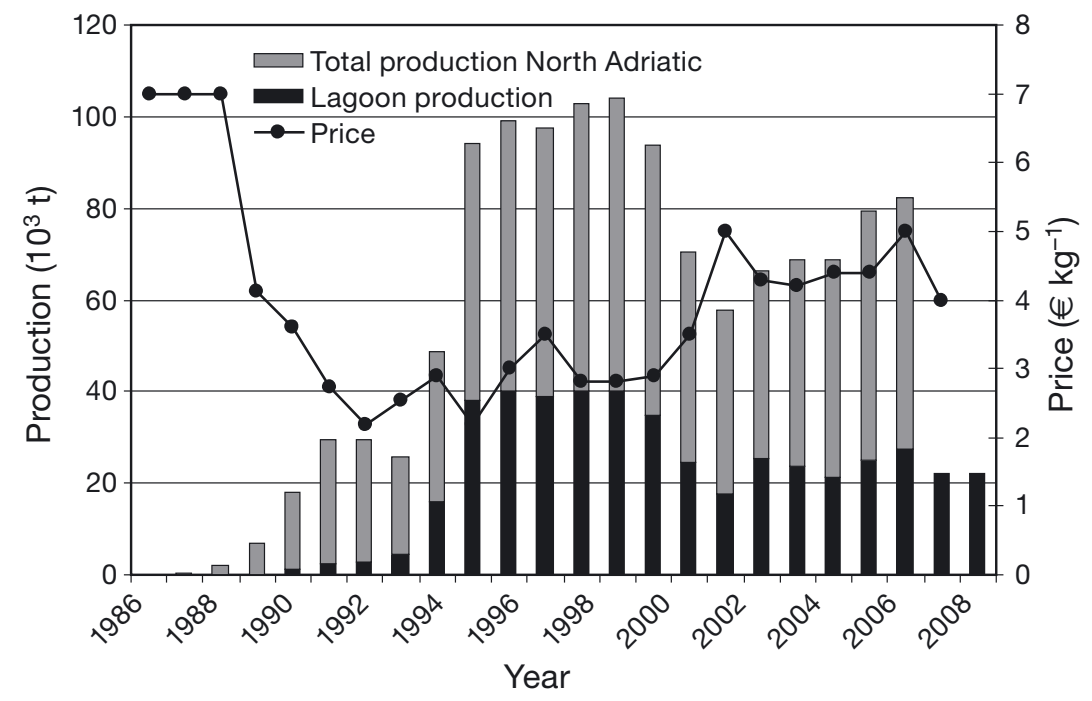

Fig. 2. Time course of price and production of clams in the lagoon of Venice and the north Adriatic lagoons. Adapted from Zentilin et al. (2008), Torricelli et al. (2009), Boatto et al. (2005), www.chioggia.org/ittico 
Venice a culture-based fishery over an area of about $30 \mathrm{~km}^{2}$ could sustain production of about $30000 \mathrm{t} \mathrm{yr}^{-1}$, which could be considered sustainable from both an environmental and a socioeconomic perspective (Pastres et al. 2001). To promote the transition to aquaculture, local authorities invited fishermen cooperatives to form a consortium (Consorzio Veneto Allevamenti Lagunari, Co.Ve.Al.La) and, in 2001, assigned about 2900 ha of the lagoon to aquaculture concessions.

However, the transition to aquaculture was less smooth than expected: Co.Ve.Al.La was not as successful as hoped and ended in 2004, while unregulated fishing was still occurring. Only in 2006 did fishermen's representatives and local authorities form a new consortium (Gestione Risorse Alieutiche Lagunari, GRAL) in charge of implementing rational management of the lagoon's fishery and aquaculture. Since then, GRAL has been in charge of managing the aquaculture of Ruditapes philippinarum in the 3220 ha assigned to this activity, social mediation of its members, implementation of good practice and collection of juveniles to be seeded in natural nursery areas. (Boatto et al. 2005, Zentilin et al. 2008, Torricelli et al. 2009). Nevertheless, optimal management policies (such as timing of seeding and harvesting in different areas) are still under discussion, illegal fishing outside of concessions is still a problem, and the implementation of rational management of aquaculture is slow (GRAL representative pers. comm.).

At present, about 1000 fishermen rear clams in the lagoon, using around 400 boats and 80 fishing vessels with vibrating dredges (Zentilin et al. 2008, Torricelli et al. 2009). Clam productivity in the leased area is estimated at $0.9 \mathrm{~kg} \mathrm{~m}^{-2} \mathrm{yr}^{-1}$, a value that could be slightly increased by the re-allocation of aquaculture concessions and improved management. In other coastal lagoons of the northern Adriatic Sea, where aquaculture has already been implemented, productivity ranges from $0.33 \mathrm{~kg} \mathrm{~m}^{-2} \mathrm{yr}^{-1}$ in the lagoon of Grado-Marano (elaboration from Zentilin et al. 2008) to $2.4 \mathrm{~kg} \mathrm{~m}^{-2} \mathrm{yr}^{-1}$ in Sacca di Goro Lagoon (elaboration from Rossi 1996). Since the trophic level of the Venice Lagoon is intermediate between the Goro and GradoMarano Lagoons, the productivity of the Venice concession could be around 1 to $2 \mathrm{~kg} \mathrm{~m}^{-2} \mathrm{yr}^{-1}$. Assuming that productivity level, devoting 3000 ha to aquaculture could potentially yield 30000 to $60000 \mathrm{t} \mathrm{yr}^{-1}$, which is higher than reported from the most productive years (Fig. 2).

\subsection{Downscaling experiment}

\subsubsection{Models}

Analysing the potential effects of climate change on local areas requires the downscaling of processes acting on a global scale. Global climate models are run at coarse spatial resolution and cannot be used directly for local studies. Downscaling methods (von Storch et al. 1993) entail integrating local and global models, often originally designed to operate at different scales

Table 1. Model components used in the downscaling experiment. TDM: trophodynamic model

\begin{tabular}{|c|c|c|c|c|c|}
\hline Model type & $\begin{array}{l}\text { Scale } \\
\text { (space, time) }\end{array}$ & $\begin{array}{l}\text { Resolution } \\
\text { (space, time) }\end{array}$ & Input & Output & Links to \\
\hline \multicolumn{6}{|l|}{$\operatorname{RegCM}$} \\
\hline $\begin{array}{l}\text { Atmospheric } \\
\text { deterministic } \\
\text { model }\end{array}$ & $\begin{array}{l}\text { European, } \\
\text { decadal }\end{array}$ & $\begin{array}{l}20 \times 20 \mathrm{~km} \\
\text { day }\end{array}$ & $\begin{array}{l}\text { General circulation model } \\
\text { output }\end{array}$ & $\begin{array}{l}\text { Irradiance, rain, } \\
\text { wind }\end{array}$ & $\begin{array}{l}\text { Rain data force StRiv, StBc. } \\
\text { Irradiance and meteo data } \\
\text { force TDM }\end{array}$ \\
\hline \multicolumn{6}{|l|}{ StRiv } \\
\hline $\begin{array}{l}\text { Statistical } \\
\text { model }\end{array}$ & $\begin{array}{l}\text { Local, } \\
\text { decadal }\end{array}$ & $\begin{array}{l}\text { Points at river } \\
\text { mouths, month }\end{array}$ & $\begin{array}{l}\text { RegCM rain output, flows } \\
\text { and nutrient concentrations } \\
\text { for rivers }\end{array}$ & Nutrient loads & Nutrient loads force TDM \\
\hline \multicolumn{6}{|l|}{ StBC } \\
\hline $\begin{array}{l}\text { Statistical } \\
\text { model }\end{array}$ & $\begin{array}{l}\text { Local, } \\
\text { decadal }\end{array}$ & $\begin{array}{l}\text { Points at lagoon } \\
\text { inlets, month }\end{array}$ & $\begin{array}{l}\text { RegCM rain output, bio- } \\
\text { chemical oceanographic } \\
\text { data }\end{array}$ & $\begin{array}{l}\text { Biochemical } \\
\text { conditions at the } \\
\text { lagoon inlets }\end{array}$ & $\begin{array}{l}\text { Conditions at inlets force } \\
\text { TDM }\end{array}$ \\
\hline \multicolumn{6}{|l|}{ TDM } \\
\hline $\begin{array}{l}\text { Biochemical } \\
\text { deterministic } \\
\text { model }\end{array}$ & $\begin{array}{l}\text { Local, } \\
\text { decadal }\end{array}$ & $\begin{array}{l}300 \times 300 \mathrm{~m} \\
\text { day }\end{array}$ & $\begin{array}{l}\text { RecCM, StRiv and StBC } \\
\text { output. Only for Cascade B: } \\
\text { clam feedback effects on } \\
\text { biogeochemical variables }\end{array}$ & $\begin{array}{l}\text { Temperature, phyto- } \\
\text { plankton, other biogeo- } \\
\text { chemical variables }\end{array}$ & $\begin{array}{l}\text { Temperature, phytoplankton } \\
\text { force ClamMod }\end{array}$ \\
\hline \multicolumn{6}{|l|}{ ClamMod } \\
\hline $\begin{array}{l}\text { Bioenergetics } \\
\text { deterministic } \\
\text { model }\end{array}$ & $\begin{array}{l}\text { Individual } \\
\text { population, } \\
\text { and annual }\end{array}$ & $\begin{array}{l}\text { Specimen and } \\
\text { cohort, day }\end{array}$ & $\begin{array}{l}\text { Temperature, phytoplankton } \\
\text { from TDM output }\end{array}$ & $\begin{array}{l}\text { Evolution of ind. length/ } \\
\text { weight, inds. cohort }{ }^{-1} \\
\text { feedback effects on bio- } \\
\text { geochemical variables }\end{array}$ & $\begin{array}{l}\text { Weight and population size } \\
\text { force economic values compu- } \\
\text { tation. Only for Cascade B: } \\
\text { clam feedback effects on TDM }\end{array}$ \\
\hline
\end{tabular}


and for different purposes. This has been accomplished either with statistical methodologies or by nesting, usually in an offline mode, a cascade of models differing in complexity and resolution (Najjar et al. 2000, Uncles 2003, Solidoro et al. 2010b). Our experiment used a hierarchy of 5 models (Table 1).

RegCM. The regional climate model RegCM (Giorgi et al. 2004a,b, Gao et al. 2006) is a 3D primitive equation model first developed by Giorgi et al. (1993a,b) and upgraded and used for a wide variety of applications, as described by Pal et al. (2007), Giorgi \& Mearns (1999) and Giorgi et al. (2006). The climate data used here were derived from the scenario simulations of Gao et al. (2006), in which the model domain encompasses the entire Mediterranean basin with $20 \mathrm{~km}$ grid spacing. Lateral boundary conditions were provided by corresponding RegCM simulations at $50 \mathrm{~km}$ grid spacing, which in turn were driven by large-scale fields from the Hadley Centre global atmospheric model HadAM3H (see Giorgi et al. 2004a, b for details). A comparison to observed data (1961-1990) shows that the model performs well in simulating meteorological and climatic parameters at the scale of the lagoon of Venice and its drainage basin (Salon et al. 2008). Here we used the A2 IPCC $\left(\mathrm{CO}_{2}\right.$ concentration of $~ 850 \mathrm{ppm}$ by 2100) scenario simulations of Gao et al. (2006). They include the reference (RF) period 1961-1990 and the period 2071-2100. The most prominent climate change signals over the Venice Lagoon are up to $5^{\circ} \mathrm{C}$ warming in the summer, increased precipitation in winter and autumn and decreased precipitation in the spring and summer (Salon et al. 2008).

TDM. The Trophodynamic Diffusive Model, TDM (Solidoro et al. 2005) is a 3D coupled physical-biogeochemical model specifically developed for the lagoon of Venice. The model uses a finite difference scheme, and the lagoon is discretised into a regular horizontal grid of $300 \times 300 \mathrm{~m}$ and a variable number of vertical layers. Transport processes are described by a simplified version of the advection-diffusion equation, which is suitable for simulating processes occurring at time scales longer than tidal cycles (Dejak et al. 1998) and reduces computational cost to acceptable values, even for multi-decadal runs. The set of biogeochemical state variables includes phytoplankton, zooplankton, nitrate, ammonia, phosphate, nutrient content in detritus and upper sediments, and dissolved oxygen. The microbial loop is implicitly included in the parameterisation of recycling processes. The model is kept as simple as possible, but it simulates the essential features of the seasonal cycles of nitrogen, phosphorus and dissolved oxygen. TDM has been used for many process studies (Solidoro et al. 1997, Dejak et al. 1998) and applications (Pastres et al. 2001, 2005) and reproduces the observed timing and magnitude of phyto- plankton evolution, spatio-temporal patterns and gradients of nutrient concentrations (Solidoro et al. 2005). The model includes a heat flux module (Dejak et al. 1992) for the computation of water temperature and a bio-optical module (Solidoro et al. 1995) for light extinction along the water column. Additional details on model setup and performances can be found in Solidoro et al. (2005). To allow multi-decadal simulations under temperature change, the functional responses of plankton growth to temperature were modified as in Solidoro et al. (2010b).

StRiv. A numerical procedure, StRiv (Cossarini et al. 2008, Solidoro et al. 2010b), computed hourly loads of nutrients from tributaries of the lagoon based on a logarithmic regression (Justic et al. 2005) between annual nutrient loads and observed precipitation, calibrated against historical data (2000-2003). Annual nutrient loads were then partitioned among the 10 major tributaries according to the proportion of their contribution to the total freshwater discharge. Daily nutrient loads were finally computed by partitioning the annual load of each river using simulated daily rain intensity.

StBC. The time course of nutrients and phytoplankton concentration at the boundaries is given by a 2 step modelling procedure, StBC (Cossarini et al. 2008, Solidoro et al. 2010b). Seasonally averaged values are first computed using a linear regression forced by seasonal precipitation (data from 1991-2004). A smoothing operator then computes a time partition of these values using daily precipitation as a template.

ClamMod. The ClamMod is a bioenergetic model that reproduces individual growth of clams as a function of water temperature, seston concentration and energy content of the seston (Solidoro et al. 2000). According to the model, if the amount of energy potentially ingested through filtration is larger than the capability of an individual to metabolise it, the growth rate is limited by metabolic processes within the clam and varies with clam size and temperature, regardless of food availability. Conversely, if the energy potentially obtained from ingested food is less than what a clam would be able to use, there is a food limitation, and growth depends on the concentration and energy content of the seston. The rates of metabolic processes increase exponentially as temperature increases from low values up to an optimum level and then decrease as temperature reaches an upper limit. Physiological thermal limits resulting from the interplay between anabolic and catabolic processes change with clam size, but optimal conditions for clam growth are around $25^{\circ} \mathrm{C}$, whereas around $30^{\circ} \mathrm{C}$ catabolic and anabolic processes equilibrate and growth stops. Anabolic processes prevail over catabolic ones at low temperatures, but the lower limit for clam growth changes significantly with size, ranging from about $13^{\circ} \mathrm{C}$ for $10 \mathrm{~mm}$ 


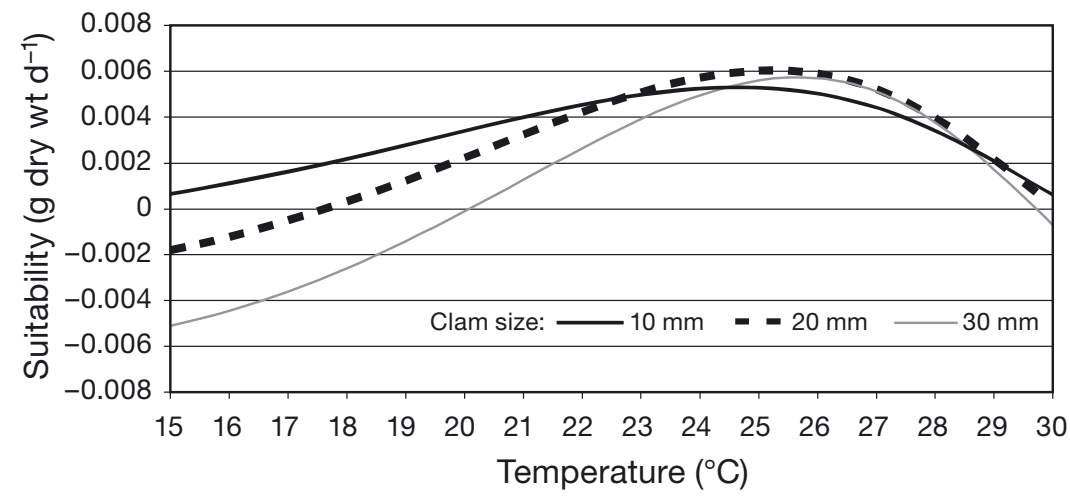

Fig. 3. Habitat suitability for clam growth as a function of water temperature and clam size (difference between anabolic and catabolic processes, assuming no food limitation)

clams up to $18^{\circ} \mathrm{C}$ for $20 \mathrm{~mm}$ clams and $20^{\circ} \mathrm{C}$ for $30 \mathrm{~mm}$ clams, so that smaller individuals have a broader thermal range (Fig. 3). The model was originally developed for the northern Adriatic Lagoon (Solidoro et al. 2000) and has been applied to evaluate the growth of farmed clams (Pastres et al. 2001, Marinov et al. 2007) and to optimise seeding times as a function of seasonal variability and environmental forcing. It also includes an age-structured population dynamics model (Solidoro et al. 2003).

\subsubsection{Model cascade configurations}

The models were linked in 2 slightly different model hierarchy configurations, Cascade A and Cascade B (Fig. 4). In both cascades, RegCM provides multidecadal projections of daily values of rain, irradiance, wind, humidity and air temperature over the drainage basin, and these data were used to force StRiv and StBC statistical models. The output from Striv and StBC then provided boundary conditions for TDM multidecadal simulations, whereas RegCM output directly forced the TDM heat fluxes and bioptical modules. TDM therefore provided space-time evolution of nitrogen, phosphorus and carbon through dissolved inorganic phases, phytoplankton, zooplankton, detritus and the upper sediment compartment. Finally, water temperature and seston concentration simulated by TDM forced ClamMod under a given management strategy. However, in Cascade $\mathrm{A}$, the coupling between TDM and ClamMod is offline, i.e. there is no feedback from ClamMod to TDM, and ClamMod can be run in a stand-alone OD mode, while in Cascade B, TDM and ClamMod are fully dynamically (online) coupled in a single 3D integrated model, and clam population dynamics alter biogeochemical properties. ClamMod had already been integrated with the TDM for evaluating the suitability of the Venice Lagoon to clam farming and for selecting areas within the lagoon best suited to clam rearing under a hypothetical scenario of environmental conditions (Pastres et al. 2001). However, that application (which relied on a 1 yr long simulation) did not include the feedback effects of clam metabolism on nutrient cycles, such as clam respiration and excretion of organic matter. In the present (multi-decadal) study, we included these processes, following Nakamura (2001) and Spillman et al. (2008). Furthermore, to allow more realistic simulations, in our study the TDM code includes planktonic adaptation to multi-decadal trends in temperature (Solidoro et al. 2010b). Additional details on the integration among RegCM, the statistical models and TDM can be found in Salon et al. (2008), Solidoro et al. (2010b) and Cossarini et al. (2008), where results of this model hierarchy reproduce present-day conditions.

Both model cascade configurations are used for the present-day reference (RF) conditions (1961-1990) and future A2 scenario conditions (2071-2100). Model Cascade A was used to explore how the time required to reach commercial size, the total harvested biomass and economic profit vary as a function of seeding time, size

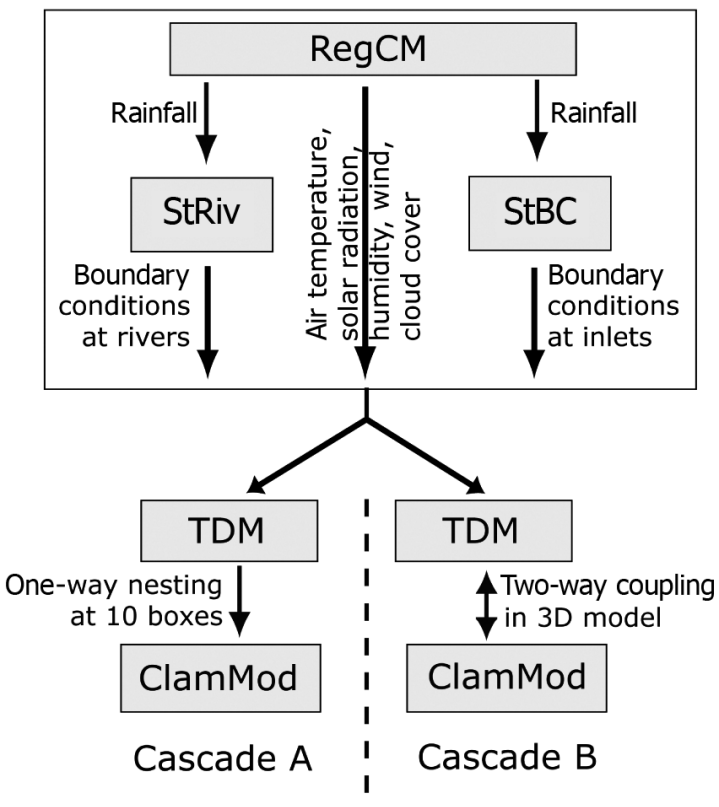

Fig. 4. Scheme of downscaling simulations. In Cascade A, inputs provided by the regional climate model (RegCM) and statistical models (StRiv and StBC) force the trophodynamic model (TDM), and TDM output forces the clam models (offline coupling). In Cascade B, input provided by RCM, StRiv and StBC force an online, 2-way coupled TDM-ClamMod model (see Section 2.2.2.) 
of seed clams and position of the aquaculture lot within the lagoon. The projections of biogeochemical properties simulated by 3D TDM were subsampled according to the 10 macro-areas (concessions) allocated to farming activities (Fig. 1), and the resulting $30 \mathrm{yr}$ time series of water temperature and seston concentration were averaged to obtain a 1 yr series representing the considered scenario. These climatological series were finally used to force the OD clam model under different management strategy scenarios (Fig. 4). For each macro-area, we ran 3 sets (with seed sizes of 2, 11 and $17 \mathrm{~mm}$ ) of 12 simulations each (varying seeding month), resulting in 360 simulations for each of the 2 climatic scenarios. Comparing the results of these simulations indicates possible 'best' strategies for each climatic scenario. Model Cascade B, in which the TDM and ClamMod models are coupled online (Fig. 4), was then used to analyse the 'best strategies' previously identified.

The Cascade B online scheme provides a more accurate representation of reality than the Cascade $\mathrm{A}$ offline scheme. However, the latter requires much less computation time, and it represents the only way to initially screen such a high number of management scenarios.

Among managing scenarios, we compared total harvested clam biomass, HarBio ( $\mathrm{t} \mathrm{ha}^{-1} \mathrm{yr}^{-1}$ ), time to harvest, TimeHar (days required to reach commercial size, $28 \mathrm{~mm}$ ) and economic revenue, EcRev (Euros ha ${ }^{-1}$ $\mathrm{yr}^{-1}$ ). Estimates of EcRev also consider major costs, such as fleet and fishing equipment depreciation, variable costs (e.g. petrol and seed) and costs related to the length of the production process (e.g. weekly visits to the sites). In agreement with GRAL (2006), seed costs are assumed to be 0.002 Euros $\mathrm{clam}^{-1}$ for $2 \mathrm{~mm}$ seed, 0.005 Euros clam ${ }^{-1}$ for $11 \mathrm{~mm}$ seed and 0.0075 Euros clam $^{-1}$ for $17 \mathrm{~mm}$ seed, while the clam price is assumed to be 3.5 Euros $\mathrm{kg}^{-1}$.

\section{RESULTS AND DISCUSSION}

\subsection{Screening of management strategies}

Cascade A model projections of biogeochemical properties have been discussed by Cossarini et al. (2008) and are summarised here to explain their effect on clam growth and population dynamics. The analysis of $30 \mathrm{yr}$ simulations referring to present-day conditions shows, at the lagoon level, a marked seasonal signal in most biogeochemical parameters (Table 2), with summers having higher temperature, higher plankton density and productivity and lower nutrient concentration than winters. Spatial gradients in the concentrations of nutrients and plankton are recognisable, with higher concentrations in the inner lagoon and in the northern basin, because of point sources of nutrients and spatial variability of residence times. Interannual variability is also present, mainly due to variability in climatic forcings used to drive the statistical and biogeochemical models. The simulation of the end of the 21st century under the A2 IPCC scenario describes a lagoon that is about $4^{\circ} \mathrm{C}$ warmer and potentially less productive because of a reduction in summer nutrient input. Changes in nutrients are more evident in the northern lagoon, but the highest changes in plankton productivity occur in the southern basin (Cossarini et al. 2008), where most aquaculture activity is located.

Because of spatial variability, the 10 areas within the lagoon devoted to clam aquaculture experience different environmental conditions. The average time course of temperature and chlorophyll a density (Fig. 5), variables driving clam dynamics and therefore determining habitat suitability for clam growth, differs across the 10 areas under both present-day and future conditions (Fig. 5).

The comparison among the 360 management scenarios under RF (1961-1990) shows the importance of

Table 2. Comparison of seasonal evolution of temperature, nutrient input and major biogeochemical properties (lagoon averages) under different climatic scenarios. Future A2 simulation results are reported as percentage anomalies from the reference (RF) scenario. DIN: dissolved inorganic nitrogen; Phyto: phytoplankton; Zoo: zooplankton; PP: primary production; SP: secondary production

\begin{tabular}{|c|c|c|c|c|c|c|c|c|}
\hline & $\begin{array}{c}T \\
\left({ }^{\circ} \mathrm{C}\right)\end{array}$ & $\begin{array}{c}\text { Input N } \\
\left(10^{3} \mathrm{~kg} \mathrm{~N} \mathrm{~d}^{-1}\right)\end{array}$ & $\begin{array}{c}\text { DIN } \\
\left(\mathrm{mg} \mathrm{N}^{-1}\right)\end{array}$ & $\begin{array}{c}\text { Phyto } \\
\left(\mathrm{mg} \mathrm{C} \mathrm{l}^{-1}\right)\end{array}$ & $\begin{array}{c}\text { Zoo } \\
\left(\mathrm{mg} \mathrm{C}^{-1}\right)\end{array}$ & $\begin{array}{c}\mathrm{PP} \\
\left(10^{3} \mathrm{~kg} \mathrm{~N} \mathrm{~d}^{-1}\right)\end{array}$ & $\begin{array}{c}\mathrm{SP} \\
\left(10^{3} \mathrm{~kg} \mathrm{~N} \mathrm{~d}^{-1}\right)\end{array}$ & $\begin{array}{l}\text { Export DIN } \\
\left(10^{3} \mathrm{~kg} \mathrm{~N} \mathrm{~d}^{-1}\right)\end{array}$ \\
\hline \multicolumn{9}{|c|}{ RF simulations (1961-1990) } \\
\hline Winter & 6.4 & 14.5 & 0.558 & 0.29 & 0.26 & 15.0 & 5.5 & -11.0 \\
\hline Spring & 20.6 & 18.1 & 0.359 & 0.70 & 0.46 & 49.0 & 14.4 & -12.4 \\
\hline Summer & 25.0 & 14.3 & 0.172 & 0.92 & 0.35 & 52.4 & 12.6 & -9.0 \\
\hline Autum & 9.7 & 19.0 & 0.593 & 0.29 & 0.27 & 16.7 & 5.7 & -14.7 \\
\hline \multicolumn{9}{|c|}{ A2 (percentage anomaly) (2071-2100) } \\
\hline Winter & 49 & 12 & 12 & -2 & 0 & -2 & 0 & 13 \\
\hline Spring & 18 & -4 & -2 & -1 & 2 & 0 & 1 & 1 \\
\hline Summer & 16 & -9 & -16 & -3 & -13 & -6 & -13 & -11 \\
\hline Autum & 37 & 8 & 7 & 1 & 2 & 2 & 3 & 7 \\
\hline
\end{tabular}




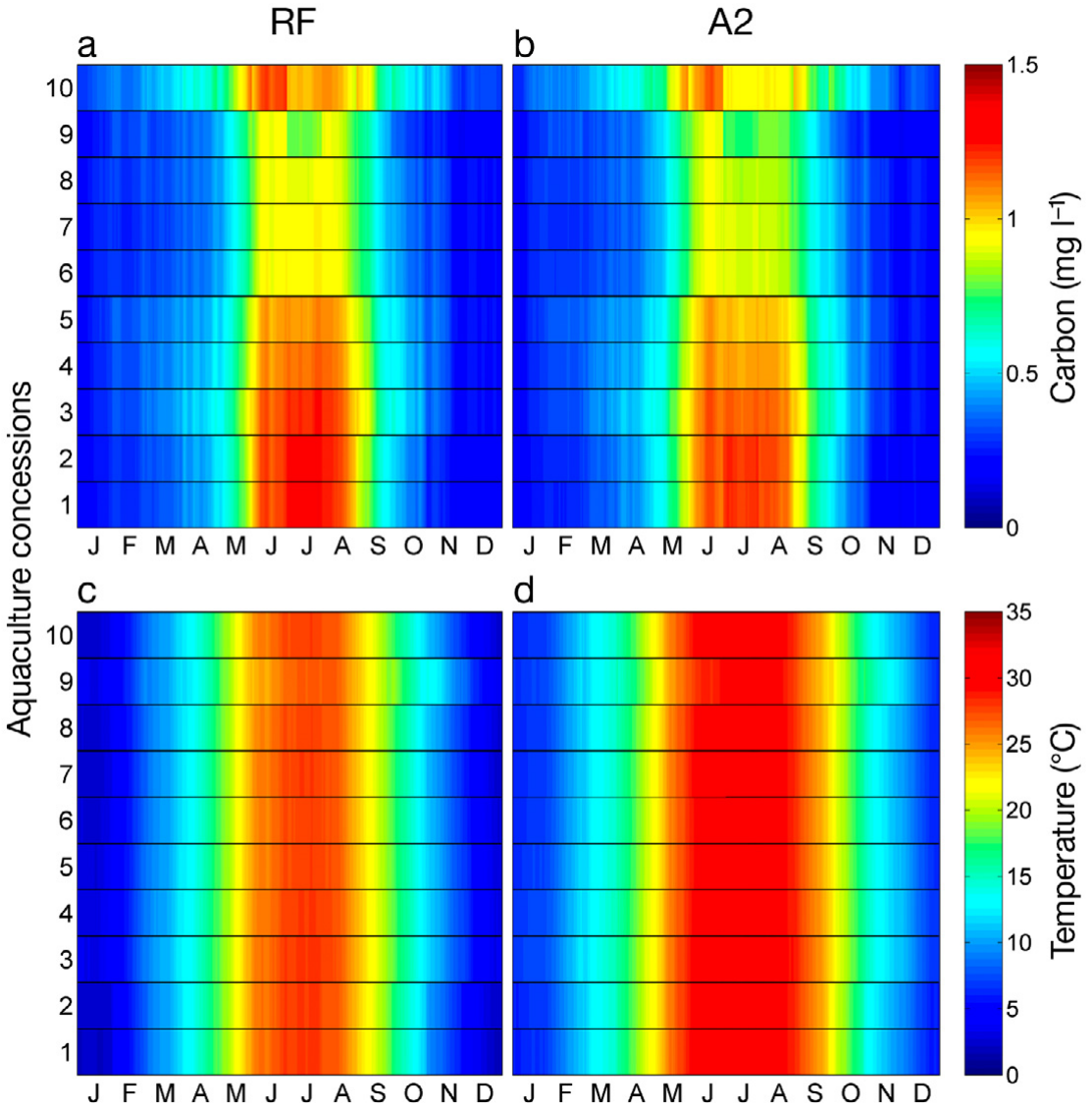

Fig. 5. Evolution of daily averaged climatological forcing used in Cascade A. $(a, b)$ phytoplankton as carbon $\left(\mathrm{mg} \mathrm{l}^{-1}\right)$ and $(\mathrm{c}, \mathrm{d})$ temperature $\left({ }^{\circ} \mathrm{C}\right)$ for $(\mathrm{a}, \mathrm{c})$ the reference (RF) simulation (1961-1990) and (b,d) the future A2 scenario (2071-2100)

much lower (about $1500 \mathrm{~g} \mathrm{~m}^{-2}$ ) when seeding in the summer or autumn.

When $11 \mathrm{~mm}$ seed is used (Fig. 6c), the optimal time window for seeding is longer. The seeding time that minimises TimeHar (Fig. 6c) and maximises HarBio (Fig. 7c) is from February to April. However, the maximum harvest (around $1700 \mathrm{~g} \mathrm{~m}^{-2}$ after seeding in March) is lower than that obtained with larger seed. Longer growing periods, about 12 to $18 \mathrm{mo}$, are required if $2 \mathrm{~mm}$ seed is used (Fig.6a), which therefore must be exposed to at least 1 cold season. In this case, summer is the optimal seeding time, which enables harvest either in the following summer, after $12 \mathrm{mo}$, or the following spring. Conversely, $18 \mathrm{mo}$ are required when seeding in autumn because, in this case, the clams experience 2 cold seasons. The use of $2 \mathrm{~mm}$ seed, therefore, gives even more flexibility in profitable seeding time but at the cost of lower HarBio (maximum of $1300 \mathrm{~g} \mathrm{~m}^{-2}$ ).

Despite the fact that longer TimeHar also implies higher costs, analysis of EcRev (Fig. 8) shows that $17 \mathrm{~mm}$ seed represents the least profitable option (mainly due to seed cost), while $11 \mathrm{~mm}$ seed yields the highest profit and $2 \mathrm{~mm}$ seed yields intermediate profits (Fig. 8).

seeding time in determining TimeHar (Fig. 6), HarBio (Fig. 7) and EcRev (Fig. 8), as well as how the optimal seeding moment varies with seeding size. In this climatic scenario, clams grow more quickly in the spring and summer, when temperatures are between 20 and $25^{\circ} \mathrm{C}$, than in fall and winter. The best strategies are therefore those that enable clams to reach commercial size before the cold season. Larger seed, which requires shorter growing periods, can be seeded in the spring and collected in the fall. In the case of $17 \mathrm{~mm}$ seed, the optimal seeding time is May, which gives a time to harvest of $<5$ mo (Fig. 6e). If clams are seeded earlier, they are also exposed to conditions less favourable to growth (colder temperature), such that TimeHar is slightly longer (about 6 mo if seeding in March). If seeded later, they do not reach commercial size before winter and must be collected the following spring, with a much longer TimeHar. Given that a longer TimeHar results in higher total mortality and a consequent decrease in biomass, HarBio (Fig. 7e) also peaks when seeding around May (about $1850 \mathrm{~g} \mathrm{~m}^{-2}$ ), is slightly lower when seeding in late winter or early spring (about $1750 \mathrm{~g} \mathrm{~m}^{-2}$ if seeding in March) and is
The maximum profit corresponds to $11 \mathrm{~mm}$ individuals seeded in the spring. A spatial variability in HarBio, TimeHar and EcREv is recognisable. Regardless of seeding size, the most productive concession is Area 9, likely because exchanges with the Adriatic Sea maintain temperature and trophic conditions at values that favour clam growth. It is also noted that several strategies give very poor financial benefit. Given the large variability in yield and costs corresponding to different management strategies, a correct policy is needed to optimise profits.

The analysis of the 360 management scenarios under the A2 climatic scenarios indicates that the optimal management strategies under future A2 climatic conditions are remarkably different from those in present-day conditions. The comparison between A2 and RF simulations (Figs. 6-8) indicates that, in general, economic yields are lower and optimal time windows for seeding are narrower under future A2 scenario conditions. The best seeding time is in late summer or late winter, rather than spring and summer. This is mostly because water temperature is higher, and spring/summer conditions are much warmer and drier in the $\mathrm{A} 2$ scenario, so that 


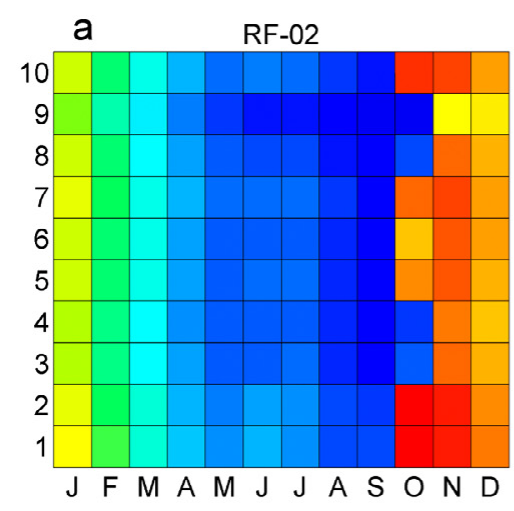

b
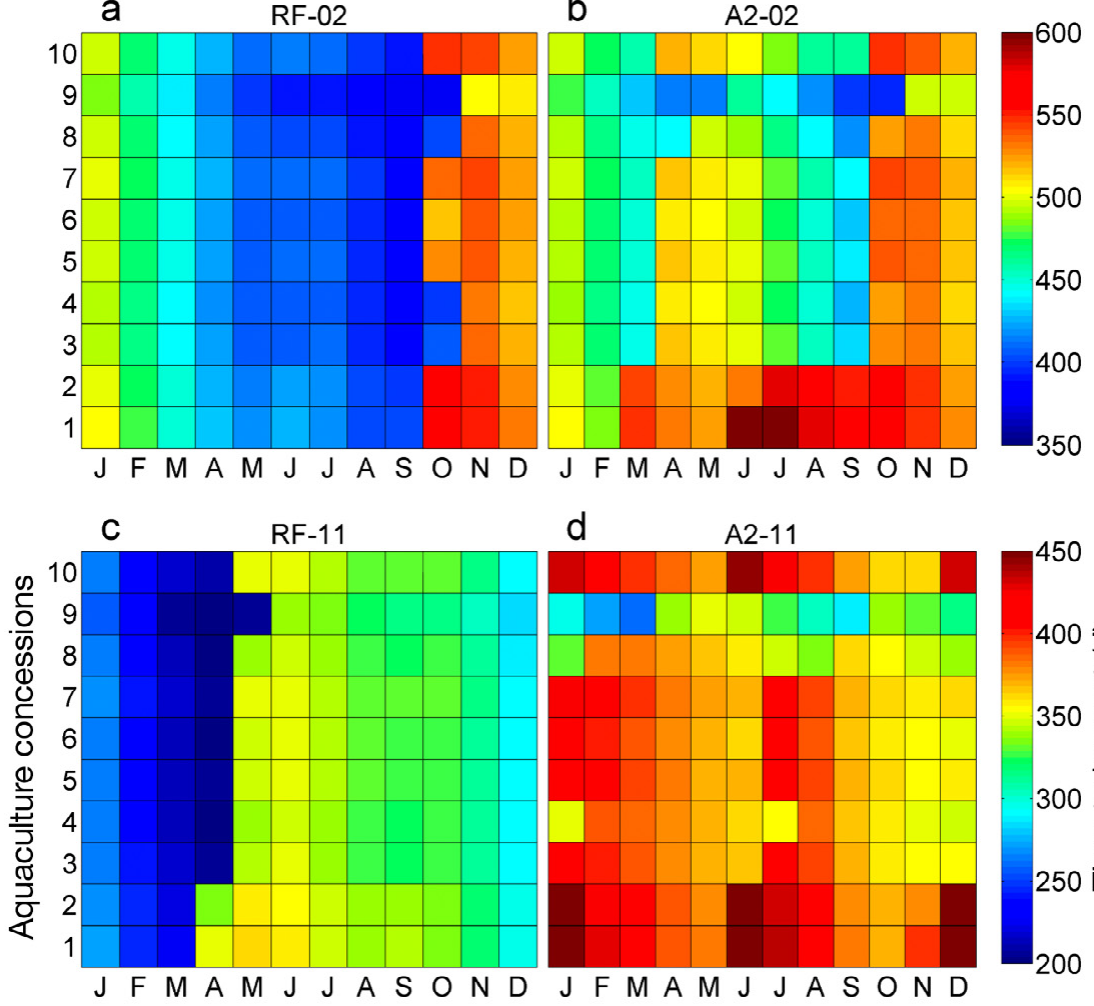

d
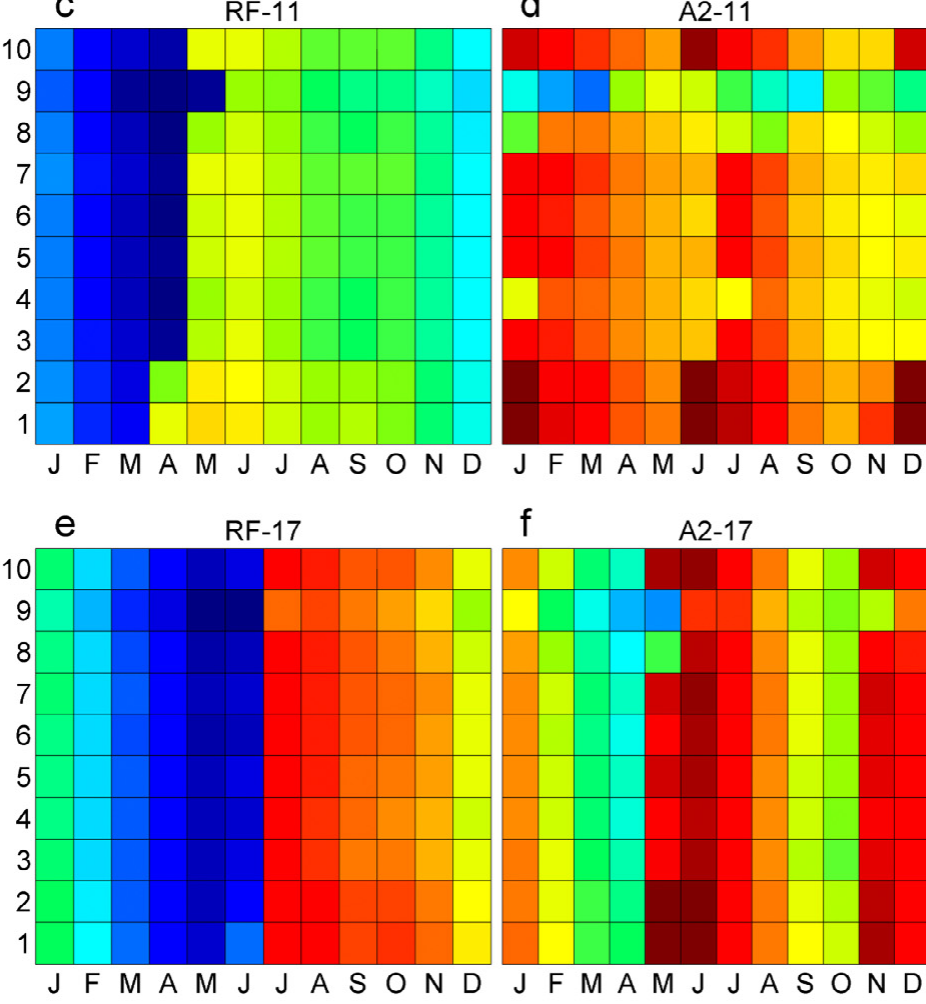

$f$

A2-17

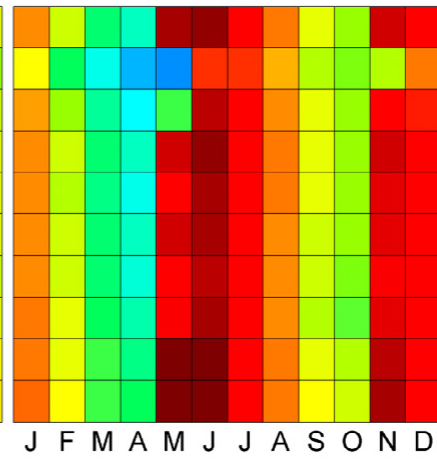

Fig. 6. 'Time to harvest' at the end of the simulation as a function of seeding month and concession (see Fig. 1). (a,c,e) reference (RF) simulation (1961-1990); (b,d,f) future A2 scenario (2071-2100). (a,b) 2 mm seed; (c,d) $11 \mathrm{~mm}$ seed; (e,f) $17 \mathrm{~mm}$ seed

summer suitability, when temperature is around $30^{\circ} \mathrm{C}$ or higher, is extremely low. Conversely, winter and autumn growth is higher than in the RF scenarios. Consequently, late summer/early autumn becomes the most suitable season for clam growth, followed by spring, winter and summer (compared to summer, spring, fall and winter in the RF scenarios).

The least profitable seed size is $17 \mathrm{~mm}$, as in the RF scenario, while $2 \mathrm{~mm}$ seed gives the highest profit and the most flexibility in seeding time. Maximum biomass yield, obtained by seeding $17 \mathrm{~mm}$ individuals in April, is about $85 \%$ of the maximum yield obtained under RF
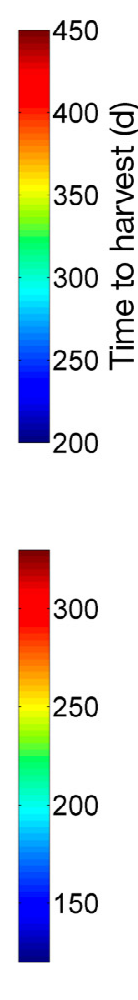

conditions by seeding $17 \mathrm{~mm}$ individuals in May. Profit in the former case is about $70 \%$ of the latter.

Therefore, and granted that economic considerations are highly sensitive to seed price and clam price fluctuations, optimal strategies referring to different climatic scenarios are quite different. To effectively face environmental alterations, including the local effects of global warming, specific management strategies based on actual conditions and adapted to future ones should be implemented.

\subsection{Present-day scenario}

To confirm the Cascade A projection, Cascade B was run under 'best' strategies, i.e. using $11 \mathrm{~mm}$ seed and seeding different areas in different months, according to indications provided by the comparison among offline simulations (Table 3). Results of the 3D online simulations performed by the Cascade B model hierarchy corroborate Cascade A results and confirm significant differences among climatic conditions. Cascade $\mathrm{B}$ projections of temperature are equal to those provided by Cascade A, while some difference can be observed in the projections of biogeochemical properties due to the feedback effects of clam dynamics. Given that clams are present only in a restricted area of the lagoon, the differences in phytoplankton concentration are not very high. However, they have a cumulative effect on the growth of clams, which are filterfeeding organisms, and therefore integrate such small variations over their lifetimes (TimeHarv).

Analysis of the online simulations shows that clam filtering significantly reduces seston concentrations. This depletion is not balanced by local plankton

Table 3. Optimal clam seeding months under the reference (RF: 1961-1990) and future A2 (2071-2100) scenarios in 10 concessions of the Venice Lagoon

\begin{tabular}{|c|c|c|c|c|c|c|c|c|c|c|}
\hline & 1 & 2 & 3 & 4 & 5 & 6 & 7 & 8 & 9 & 10 \\
\hline $\mathrm{RF}$ & \multirow{2}{*}{\multicolumn{2}{|c|}{$\begin{array}{c}\text { March } \\
\text { October }\end{array}$}} & & & & \multirow{2}{*}{\multicolumn{3}{|c|}{ April }} & \multirow{2}{*}{\multicolumn{2}{|c|}{ Mar. Nov. }} \\
\hline A2 & & & 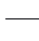 & 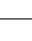 & & & & & & \\
\hline
\end{tabular}




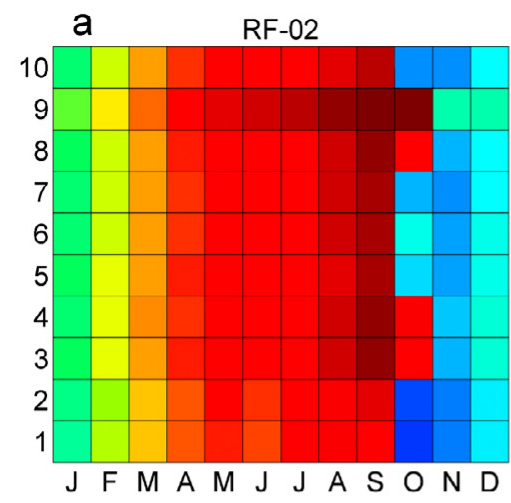

b
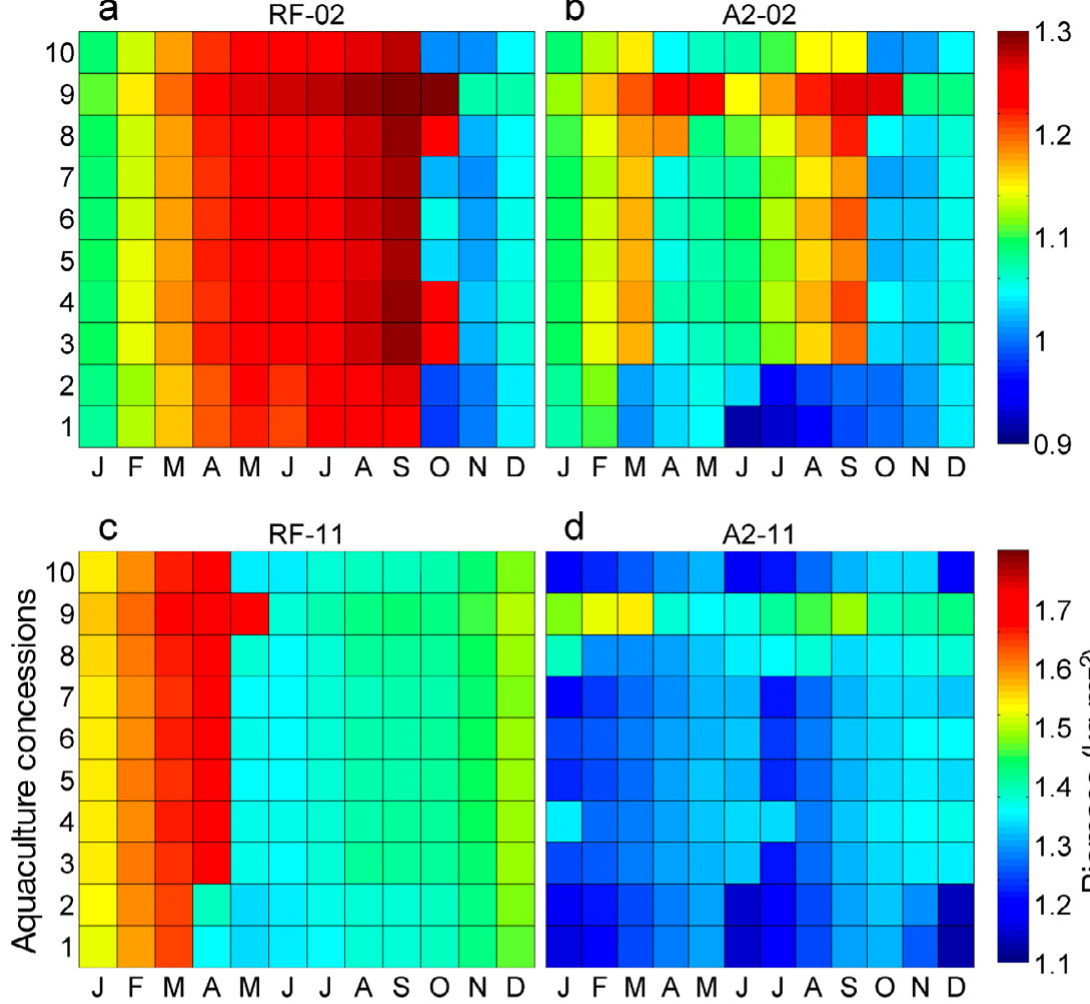

d

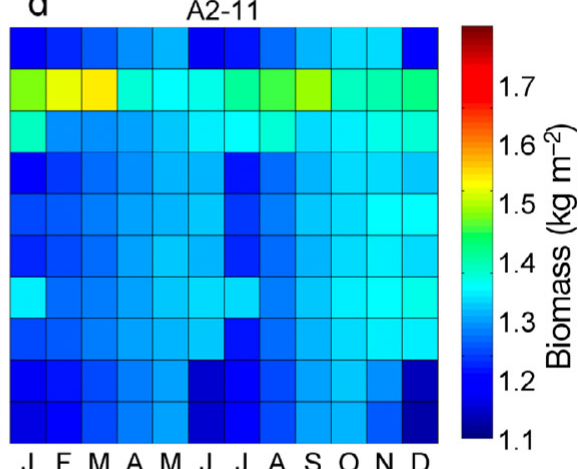

f

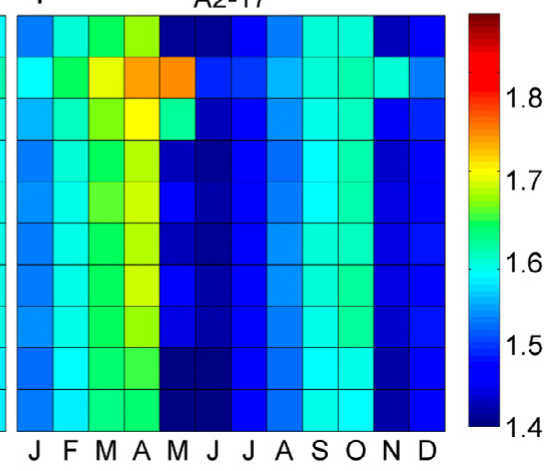

Fig. 7. Biomass at the end of the simulation as a function of seeding month and concession (see Fig. 1). (a,c,e) reference (RF) simulation (1961-1990); (b,d,f) future A2 scenario (2071-2100). (a,b) $2 \mathrm{~mm}$ seed; (c,d) $11 \mathrm{~mm}$ seed; (e,f) $17 \mathrm{~mm}$ seed

growth or net fluxes of seston from outside the concession and eventually results in food limitation. This effect, which could not be modelled in the offline coupled models used in Cascade A, is more evident in concessions located in shallow areas far from major channels, where tidal mixing is low (such as Areas 1 and 2). It is also evident in larger concessions (Area 1), in which spatial gradients of plankton density arise because clams seeded at the boundaries of aquaculture lots filter most of the lateral input of seston, with clams in the centre experiencing reduced flow. Conversely, it is reduced in Concession 9, because of ses- ton supply along major channels connecting the lagoon to the external Adriatic Sea.

The comparison between Cascade B simulations of 10 areas devoted to aquaculture and the corresponding subset of Cascade A simulations also assessed whether Cascade A is adequate for a first screening of management options. Under RF climatic conditions, biomass predicted by online simulations is systematically slightly lower $(10 \%)$ than that in offline simulations, mainly because high frequency forcings (30 yr of hourly values of temperature and seston) drive clam dynamics in Cascade B, whereas average values are used in Cascade A. However, the ranking among different macroareas is generally preserved, in terms of both TimeHar and HarBio. Thus, the Cascade A hierarchy can indeed be used for initial screening of optimal management strategies.

Online simulations project a potential production of $49.3 \times 10^{6} \mathrm{t} \mathrm{yr}^{-1}$ for the entire lagoon under RF conditions. Average productivity is around $1.6 \mathrm{~kg}$ $\mathrm{m}^{-2} \mathrm{yr}^{-1}$, which is higher than estimated for current conditions. However, yearto-year production varies within the $30 \mathrm{yr}$ period from 42 to $56 \times 10^{6} \mathrm{t} \mathrm{yr}^{-1}$ because of the variability in actual meteorological conditions (Fig. 9). Area 9 is still the most productive, with about $1.7 \mathrm{~kg} \mathrm{~m}^{-2} \mathrm{yr}^{-1}$ of biomass and a time to harvest of about 6 mo. The high productivity of this concession is due to its particular shape and location, being composed of several small areas located close to the inlets of Chioggia and crossed by a network of deep ( $>3 \mathrm{~m}$ ) channels, which favour efficient water exchange with the Adriatic Sea. Other highly productive concessions are Areas 4, 6, 3, 8 and 10, which are all seeded in April. However, we stress that our projections provide only a first-order estimate of biomass production and profit, and several factors were not considered. The optimal seeding strategies used in the online simulation might not be implementable since yields of different lots are maximised independently without considering that the harvest should be distributed over time to avoid price fluctuations. Similarly, other constraints should be taken into account, such as seed availability, weather conditions and risks related to extreme events (e.g. storms or 


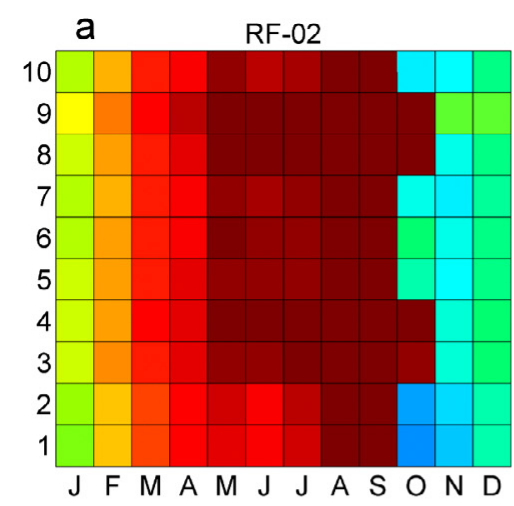

b
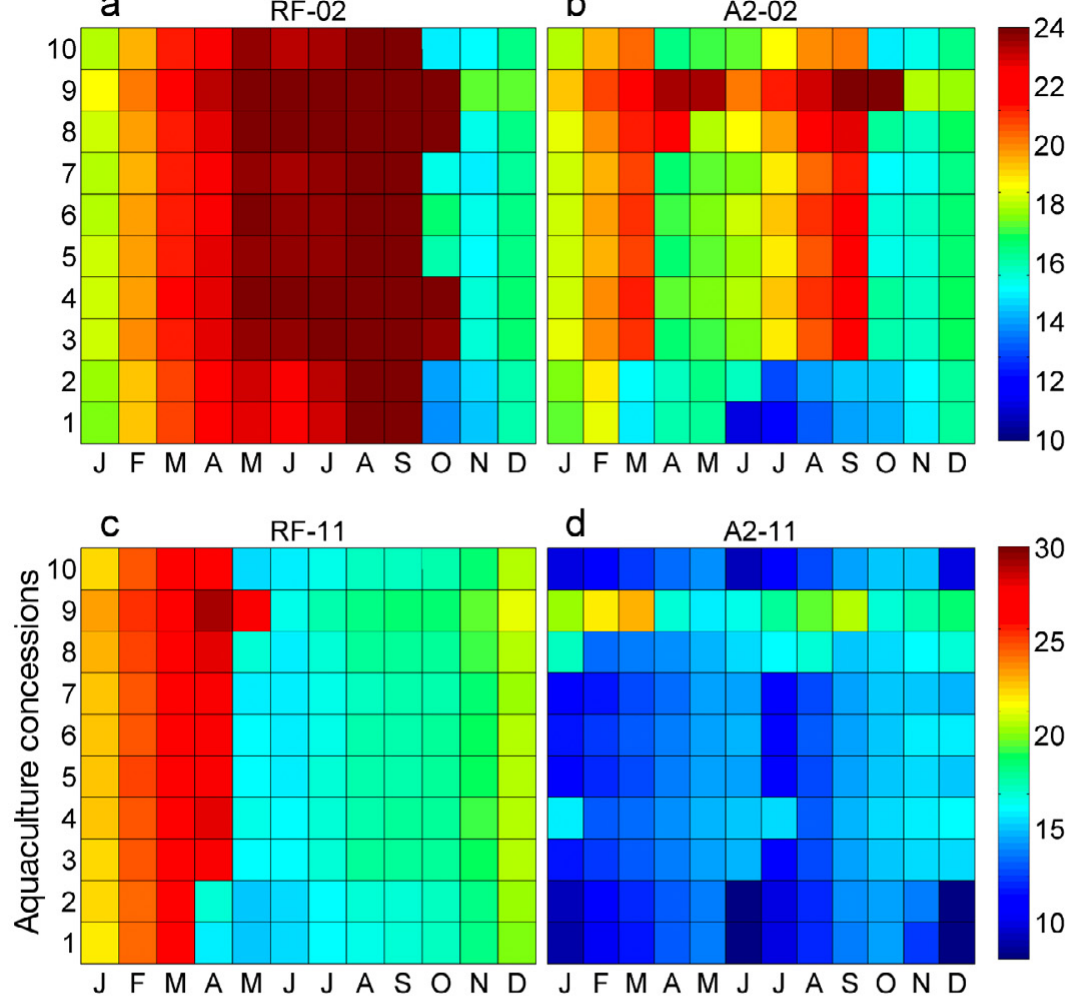

d
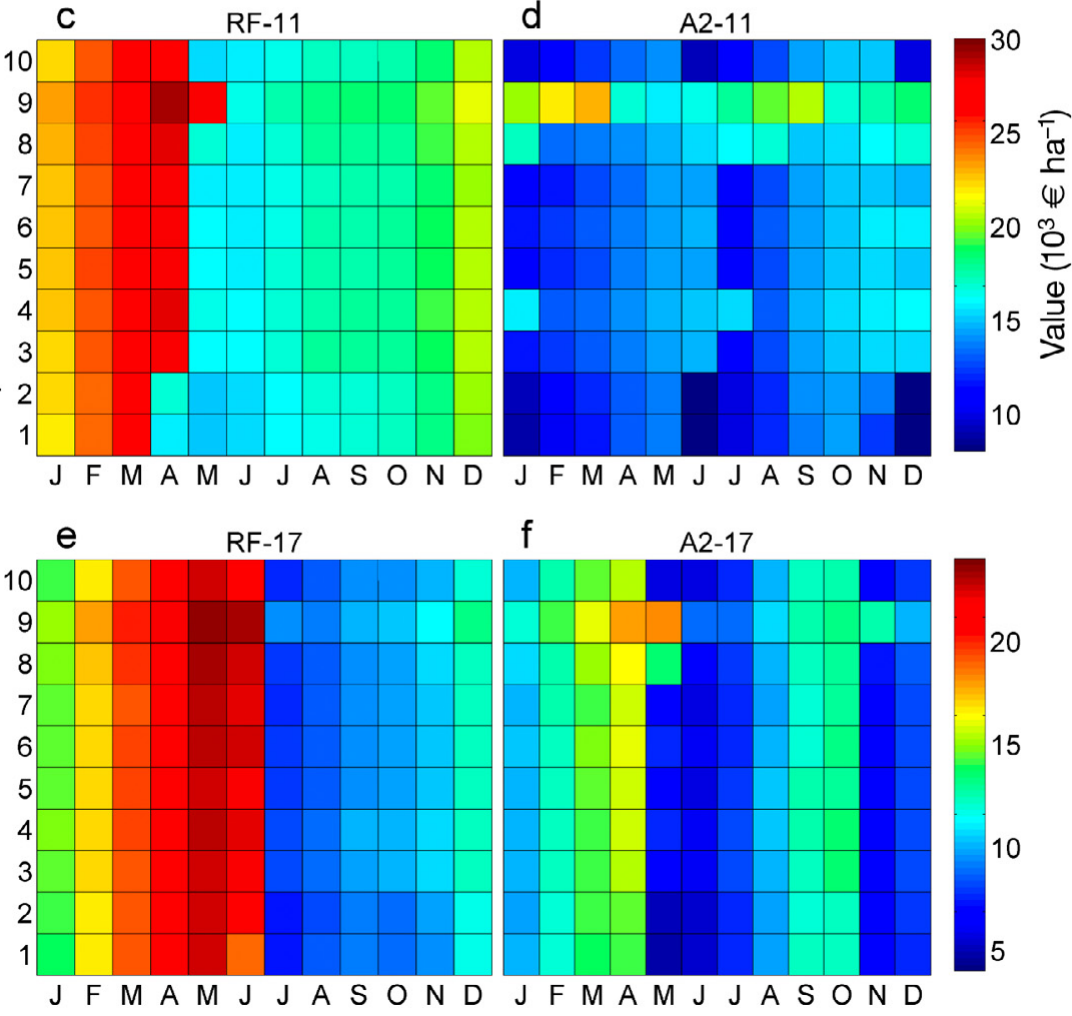

Fig. 8. Economic value $\left(10^{3}\right.$ Euros ha $\left.{ }^{-1}\right)$ at the end of simulation as a function of seeding month and concession (see Fig. 1). (a,c,e) reference (RF) simulation (1961-1990); (b,d,f) future A2 scenario (2071-2100). (a,b) $2 \mathrm{~mm}$ seed; (c,d) $11 \mathrm{~mm}$ seedi $_{(\mathrm{e}, \mathrm{f})} 17 \mathrm{~mm}$ seed

environmental crises such as anoxia). Conversely, profit might be increased by compensation mechanisms, such as lot rotation or subsidies for less productive lots. However, the aim of this paper was not the actual identification of an optimal management plan (which is such a complex task as to require a separate study) but a comparison of plans under 2 alternative climatic scenarios to illustrate the variability associated with different management options. Even with these caveats, the total annual biomass is still similar to the landings in the last years of an open access strategy (Fig. 2).

\subsection{Future scenario}

Projections under the future scenario A2, assuming an optimal management scenario (seeding months as in Table3), indicate a total clam biomass of $43.15 \times 10^{6} \mathrm{t} \mathrm{yr}^{-1}$, which is significantly lower than in the RF conditions (Fig. 9). The difference is mainly caused by clam response to higher water temperatures and, to a lesser extent, by changes in seasonal patterns of freshwater and nutrient input from rivers, which may cause an increase in nutrient exports to the Adriatic Sea in winter and a reduction of spring and summer nutrient concentrations and plankton productivity (Cossarini et al. 2008). Future spatial variability in clam productivity is lower than at present (Fig. 10), and concessions 10,4 and 5 become the most productive areas. In this scenario, yields in less productive years can be as low as 38 $\times 10^{6} \mathrm{t} \mathrm{yr}^{-1}$, which is equivalent to a productivity of $1.1 \mathrm{~kg} \mathrm{~m}^{-2} \mathrm{yr}^{-1}$. Considering this, we stress once again that model projections are estimates to be used for comparison to other scenarios rather than as absolute indicators.

Moreover, when considering projections of future clam productivity, there is an additional source of uncertainty, i.e. thermal adaptation. As already remarked, in our experiment we assumed that phytoplankton organisms adapt to multi-decadal trends in temperature. In principle, a similar assumption can also be made for clams. However, since clams live longer than plankton and produce fewer new generations per year, their adaptation would take more time. Furthermore, since in the lagoon of Venice clams are artificially seeded, there may be a continuous import and mixing of genetic material from different environments. Therefore, we assumed that no significant adaptation occurred over the period considered and that clams respond to future water temperature as in present-day conditions. This simulation (no adaptation) might be seen as the upper limit of an envelope of model simulations made by considering different degrees of adaptation for phytoplankton and for clams. If some adaptation to a new temperature regime does take place in clams, biomass projections would be intermediate between the RF and A2 projections. 


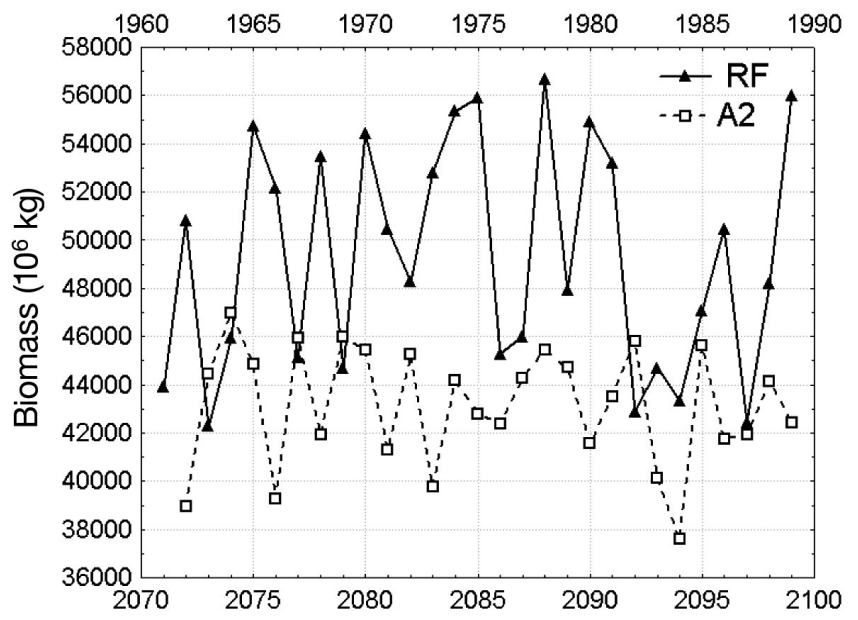

Fig. 9. Time course of the annual total biomass production in the reference $(\mathrm{RF} ; 1961-1990)$ and future A2 (2071-2100) scenarios

The general trend, however, is towards a significant reduction in clam productivity, with remarkably low values in less favourable years. Finally, we note that the implementation of RF optimal management policies (seeding months as in Table 3, simulation not shown) in the future scenario conditions would give much lower production rates, which points to the need for effective management adaptation options. Our

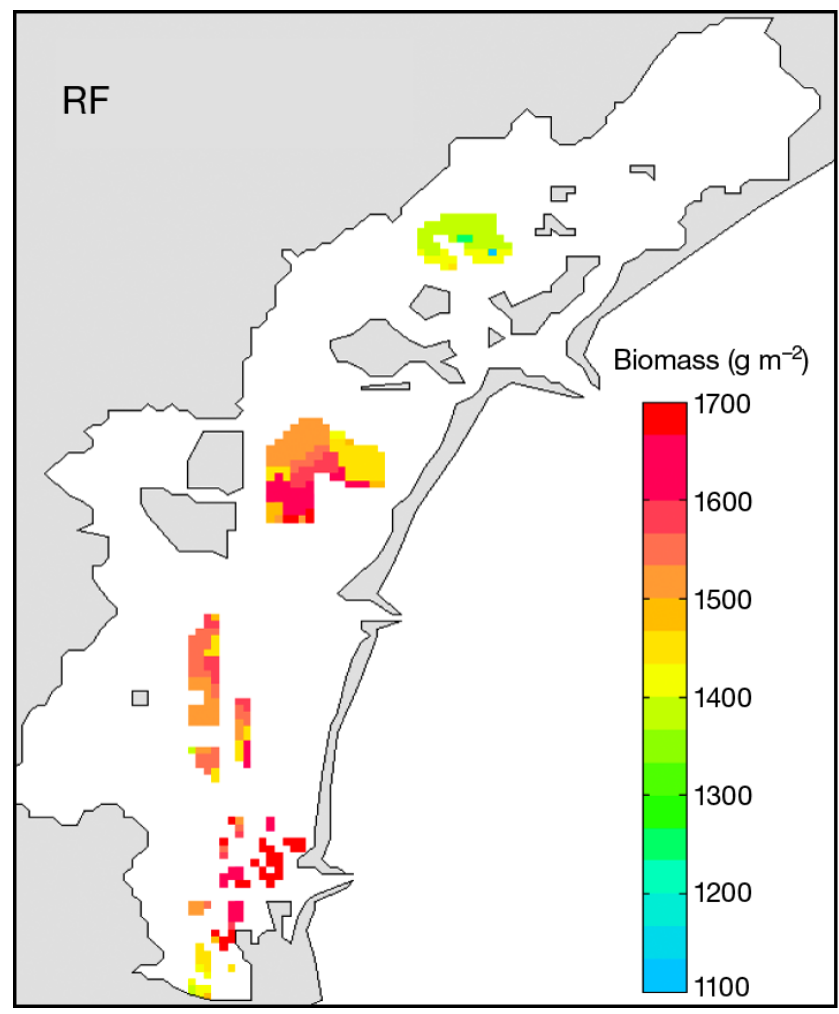

results thus indicate that management strategies based on future conditions may efficiently mitigate the reduction in productivity potentially induced by GC.

Our conclusions are strictly valid only for the study area. However, since they do not depend critically on any peculiarities of the lagoon of Venice, they can be generalised to any coastal area likely to experience similar changes in water temperature and rain seasonality. Therefore, besides providing a methodological example for analysing climate-change impacts on coastal ecosystems and the goods and services they provide, our results can provide insight into the effects of GC on coastal areas along with the effectiveness of different management policies.

\section{CONCLUSIONS}

This study presents one of the first exercises linking climate change forcing to local ecosystem and target species population dynamics models to evaluate the effect of climate change scenarios on a temperate coastal lagoon, along with the goods and services provided by this ecosystem. Our analysis of GC effects on coastal ecosystems accounts not only for modifications in meteorological forcings (e.g. air temperature, precipitation and wind) but also for changes in nutrient

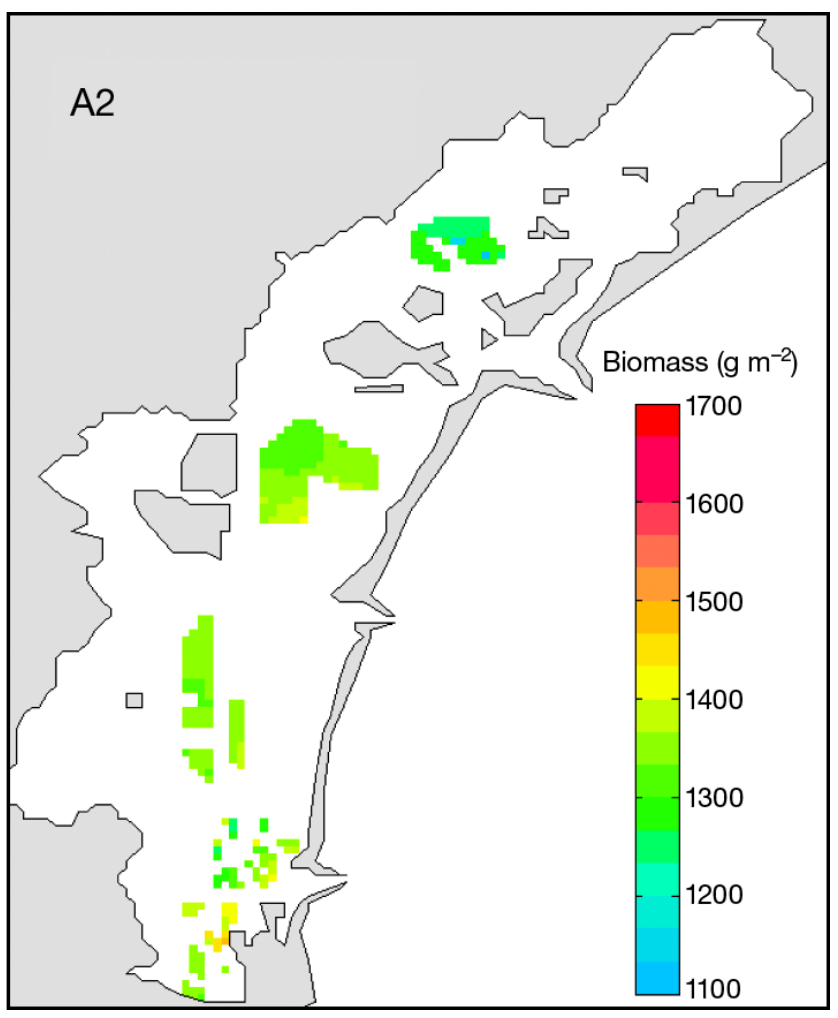

Fig. 10. Spatial distribution of the average harvested biomass over a 30 yr simulation under (a) reference (RF; 1961-1990) and (b) future A2 (2071-2100) scenarios 
inputs from land, both in absolute values and in temporal patterns. We parameterised these inputs within a hierarchy of models that downscaled global effects to local scales.

The direct effects of changes in water temperature and the indirect effects of reductions in plankton productivity caused by the modifications in temperature and in input of nutrients from land will affect habitat suitability for Ruditapes philippinarum. The main impacts are due to direct effects. Our simulations show that aquaculture will suffer under projected future climate conditions and point to a need for site- and condition-specific adaptive aquaculture management, which can mitigate the adverse effects of GC. This conclusion can be generalised to other temperate coastal systems and might be of particular importance in ecological-social-economic systems where clam farming is crucial for a self-sustaining economy.

Acknowledgements. We thank S. Libralato and S. Salon for help, discussion and information on the input data. This work was partially funded by the European Union's 6th Framework Program SPICOSA and by the Centro Euro-Mediterraneo per i Cambiamenti Climatici (CMCC). This work is a contribution to the IMBER and GLOBEC programs.

\section{LITERATURE CITED}

Bandelj V, Socal G, Park YS, Lek S, Coppola J, Camatti E, Capuzzo E, Dilani L, Solidoro C (2008) Multitrophic assemblage of plankton communities in the lagoon of Venice. Mar Ecol Prog Ser 368:23-40

Bandelj V, Curiel D, Lek S, Rismondo A, Solidoro C (2009) Modelling spatial distribution of hard bottom benthic communities and their functional response to environmental parameters. Ecol Model 220:2838-2850

Boatto V, Silvestri S, Rossetto L (2005) Analisi economica della filiera di Tapes philippinarum. In: Boatto B, Pellizzato M (eds) La filiera della vongola. Franco Angeli, Milano, p 119-131

Boesch DF, Field JC, Scavia D (2000) The potential consequences of climate variability and change on coastal areas and marine resources. U.S. national assessment of the potential consequences of climate variability and change, U.S. Global Change Research Program. NOAA Coastal Ocean Program Decision Analysis Ser No. 21, NOAA Coastal Ocean Program, Silver Spring, MD

Cossarini G, Libralato S, Salon S, Gao X, Giorgi F, Solidoro C (2008) Downscaling experiment for the Venice lagoon. II. Effects of changes in precipitation on biogeochemical properties. Clim Res 38:45-61

Cossarini G, Lermusiaux PFJ, Solidoro C (2009) The Lagoon of Venice ecosystem: seasonal dynamics and environmental guidance with uncertainty analyses and error subspace data assimilation. J Geophy Res 114:C06026, doi:10.1029/ 2008JC005080

Cucco A, Umgiesser G, Ferrarin C, Perilli C, Melaku Canu D, Solidoro C (2009) Eulerian and Lagrangian transport time scales of a tidal active coastal basin. Ecol Model 220: 913-922

Dejak, C, Franco D, Pastres R, Pecenik G, Solidoro C (1992)
Thermal exchanges at air-water interfaces and reproduction of temperature vertical profiles in water columns. J Mar Syst 3:465-476

Dejak C, Pastres R, Polenghi I, Solidoro C, Pecenik G (1998) 3D modelling of water quality transport processes with time and space varying diffusivity. Coast Estuar Stud 54: 645-662

Dekshenieks MM, Hofmann EE, Klinck JM, Powell EN (2000) Quantifying the effects of environmental change on an oyster population: a modeling study. Estuaries 23: 593-610

FAO (2008) Report of the FAO Expert Workshop on Climate Change Implications for Fisheries and Aquaculture. Rome, Italy, 7-9 April 2008. FAO Fish Rep. No. 870. FAO, Rome

Gao X, Pal JS, Giorgi F (2006) Projected changes in mean and extreme precipitation over the Mediterranean region from a high resolution double nested RCM simulation. Geophys Res Lett 33:L03706, doi:10.1029/2005GL024954

Giorgi F, Mearns LO (1999) Introduction to the special section: regional climate modelling revisited. J Geophys Res 104:6335-6352

> Giorgi F, Marinucci MR, Bates GT (1993a) Development of a second-generation regional climate model (RegCM2). I. Boundary-layer and radiative transfer processes. Mon Weather Rev 121:2794-2813

Giorgi F, Marinucci MR, Bates GT, De Canio G (1993b) Development of a second-generation regional climate model (RegCM2). II. Convective processes and assimilation of lateral boundary conditions. Mon Weather Rev 121: 2814-2832

> Giorgi F, Bi X, Pal JS (2004a) Mean, interannual variability and trends in a regional climate change experiment over Europe. I. Present-day climate (1961-1990). Clim Dyn 22: 733-756

Giorgi F, Bi X, Pal JS (2004b) Mean, interannual variability and trends in a regional climate change experiment over Europe. II. Climate change scenarios (2071-2100). Clim Dyn 23:839-858

Giorgi F, Pal JS, Bi X, Sloan L, Elguindi N, Solmon F (2006) Introduction to the TAC special issue: the RegCNET network. Theor Appl Climatol 86:1-4

GRAL (Gestione Risorse Alieutiche Lagunari) (2006) Piano d'uso sostenibile delle aree in concessione per venericoltura. GRAL Tech Rep, Venice

Guelorget O, Perthuisot J (1992) Paralic ecosystems. Biological organization and functioning. Vie Milieu 42:215-251

Harley CDG, Hughes AR, Hultgren KM, Miner BG and others (2006) The impacts of climate change in coastal marine systems. Ecol Lett 9:228-241

Hulme PE (2005) Adapting to climate change: is there scope for ecological management in the face of a global threat? J Appl Ecol 42:784-794

Jones RN, Leemans R, Mearns LO, Nakicenovic N and others (2001) Developing and applying scenarios. In: McCarthy JJ, Canziani OF, Leary NA, Dokken DJ, White KS (eds) Climate change 2001: impacts, adaptation and vulnerability. Contribution of Working Group II to the Third Assessment Report of the Intergovernmental Panel on Climate Change. Cambridge University Press, Cambridge

Justic D, Rabalais NN, Turner RE (2005) Coupling between climate variability and coastal eutrophication: evidence and outlook for the northern Gulf of Mexico. J Sea Res 54:25-35

Marchini A, Marchini C (2006) A fuzzy logic model to recognise ecological sectors in the Lagoon of Venice based on the benthic community. Ecol Model 193:105-118

> Marinov D, Galbiati L, Giordani G, Viaroli P, Norro A, Bencivelli S, Zaldívar JM (2007) An integrated modelling 
approach for the management of clam farming in coastal lagoons. Aquaculture 269:306-320

Melaku Canu D (1998) Tapes philippinarum nelle lagune dell'Alto Adriatico. Analisi modellistica in relazione alle variabili ambientali ed aspetti socioeconomici. MS thesis, University ca Foscari, Venice

Melaku Canu D, Solidoro C, Pastres R, Umgiesser G (2002) Tapes philippinarum in the lagoon of Venice: a socioeconomic-environmental analysis and suggestions for a more efficient harvesting strategy. Selected Proc Int Conf Sustainable Management of Coastal Ecosystems. Eicoes Universidade Fernando Pessoa, University of Porto, p 247-256

Melaku Canu D, Solidoro C, Umgiesser G (2003) Modelling the response of the lagoon of Venice ecosystem to variation in the physical forcings. Ecol Model 170:265-290

Najjar RG, Walker HA, Anderson PJ, Barron EJ and others (2000) The potential impacts of climate change on the Mid-Atlantic Coastal Region. Clim Res 14:219-233

Nakamura Y (2001) Filtration rates of the Manila clam, Tapes philippinarum: dependence on prey items including bacteria and picocyanobacteria. J Exp Mar Biol Ecol 266: 181-192

Nicholls RJ, Wong PP, Burkett VR, Codignotto JO and others (2007) Coastal systems and low lying areas. In: Parry ML, Canziani OF, Palutikof JP, van der Linden PJ, Hanson CE (eds) Climate change 2007: impacts, adaptation and vulnerability. Contribution of Working Group II to the Fourth Assessment Report of the Intergovernmental Panel on Climate Change. Cambridge University Press, Cambridge, p 315-356

Orel G, Boatto V, Sfriso A Pellizzato M (2000) Assessorato alla caccia, pesca e polizia provinciale. Piano per la gestione delle risorse alieutiche delle lagune della provincia di Venezia. Provincia di Venezia, Venice

Pal JS, Giorgi F, Bi X, Elguindi N and others (2007) Regional climate modelling for the developing world: the ICTP RegCM3 and RegCNET. Bull Am Meteorol Soc 88: 1395-1409

Pastres R, Solidoro C, Cossarini G, Melaku Canu D, Dejak C (2001) Managing the rearing of Tapes phillipinarum in the lagoon of Venice: a decision support system. Ecol Model 138:231-245

Pastres R, Ciavatta S, Cossarini G, Solidoro C (2005) The seasonal distribution of dissolved inorganic nitrogen and phosphorus in the Venice lagoon: a numerical analysis. Environ Int 31:1031-1039

Pellizzato M (1990) Acclimazione della specie Tapes philippinarum e primi allevamenti in Italia. In: Alessandra $G$ (ed), Tapes philippinarum-Biologia e sperimentazione. ESAV (Ente per lo Sviluppo Agricolo del Veneto), Venice, p $157-170$

Pellizzato M, Da Ros L (2005) Clam farming quality as a management tool: a proposal based on recent studies in Northern Adriatic lagoons. Aquac Int 13:57-66

Rossi R (1996) Allevamento di vongola verace filippina (Tapes philippinarum) Gestione della semina e del trasferimento in banco naturale per la ottimizzazione del raccolto. Tech Rep D.M. 04/92, 18/2/1993, University of Ferrara

Salon S, Cossarini G, Libralato S, Gao X, Solidoro C, Giorgi F (2008) Downscaling experiment for the Venice lagoon. I. Validation of the present-day precipitation climatology. Clim Res 38:31-41

Scavia D, Field JC, Boesch DF (2003) Forecasting climate impacts on coastal ecosystems. In: Valette-Silver NJ, Scavia $\mathrm{D}$ (eds) Ecological forecasting: new tools for coastal and ecosystem management. NOAA Tech Memo NOS NCCOS $1: 23-28$

Solidoro C, Dejak C, Franco D, Pastres R, Pecenik G (1995) A model for macroalgae and phytoplankton growth in the Venice Lagoon. Int Environ 21:619-626

Solidoro C, Brando VE, Dejak C, Franco D, Pastres R, Pecenik $\mathrm{G}$ (1997) Long term simulations of population dynamics of Ulva $r$. in the lagoon of Venice. Ecol Model 102:259-272

Solidoro C, Pastres R, Melaku Canu D, Pellizzato M, Rossi R (2000) Modelling the growth of Tapes philippinarum in Northern Adriatic lagoons. Mar Ecol Prog Ser 199:137-148

Solidoro C, Melaku Canu D, Rossi R (2003) Ecological and economic considerations on fishing and rearing of Tapes phillipinarum in the lagoon of Venice. Ecol Model 170: 303-318

Solidoro C, Melaku Canu D, Cucco A, Umgiesser G (2004a) A partition of the Venice Lagoon based on physical properties and analysis of general circulation. J Mar Syst 51:147-160

Solidoro C, Pastres R, Cossarini G, Ciavatta S (2004b) Seasonal and spatial variability of water quality parameters in the Venice lagoon. J Mar Syst 51:7-18

Solidoro C, Pastres R, Cossarini G (2005) Nitrogen and plankton dynamics in the lagoon of Venice. Ecol Model 184: 103-124

Solidoro C, Bandelj B, Aubry Bernardi F, Camatti E and others (2010a) Response of Venice Lagoon ecosystem to natural and anthropogenic pressures over the last 50 years. In: Kennish MJ, Paerl HW (eds) Coastal lagoons: critical habitats of environmental change. CRC Press, Boca Raton, FL (in press)

Solidoro C, Cossarini G, Libralato S, Salon S (2010b) Remarks on the redefinition of system boundaries and model parameterization for downscaling experiments. Prog Oceanogr 84:134-137

Spillman CM, Hamilton DP, Hipsey MR, Imberger J (2008) A spatially resolved model of seasonal variations in phytoplankton and clam (Tapes philippinarum) biomass in Barbamarco Lagoon, Italy. Estuar Coast Shelf Sci 79: $187-203$

Spillman CM, Hamilton DP, Imberger J (2009) Management strategies to optimise sustainable clam (Tapes philippinarum) harvests in Barbamarco Lagoon, Italy. Estuar Coast Shelf Sci 81:267-278

Torricelli P, Boatto V, Franzoi P, Pellizzato M, Silvestri S (2009) Piano per la gestione delle risorse alieutiche delle lagune della provincia di Venezia. Provincia di Venezia, Venice

Uncles RJ (2003) From catchment to coastal zone: examples of the application of models to some long-term problems. Sci Total Environ 314-316:567-588

- Vichi M, May W, Navarra A (2003) Response of a complex ecosystem model of the northern Adriatic Sea to a regional climate change scenario. Clim Res 24:141-158

- Vincenzi S, Caramori G, Rossi R, De Leo GA (2006) A GISbased habitat suitability model for commercial yield estimation of Tapes philippinarum in a Mediterranean coastal lagoon (Sacca di Goro, Italy). Ecol Model 193:90-104

> von Storch H, Zorita E, Cubasch U (1993) Downscaling of global climate change estimates to regional scales: an application to Iberian rainfall in wintertime. J Clim 6:1161-1171

Zentilin A, Pellizzato M, Rossetti E, Turolla E (2008) La venericoltura in Italia a 25 anni dal suo esordio. Pesce (Modena) 3:31-50

Submitted: May 6, 2009; Accepted: March 17, 2010

Proofs received from author(s): April 28, 2010 